\title{
Appendix 1. Authors and their papers: a guidance sheet for authors and writers
}

Book or Report Section

Published Version

Creative Commons: Attribution-Noncommercial-No Derivative Works 4.0

Open Access

Sutton, D. C. (2018) Appendix 1. Authors and their papers: a guidance sheet for authors and writers. In: Sutton, D. C. and Livingstone, A. (eds.) The Future of Literary Archives:

Diasporic and Dispersed Collections at Risk. ARC, pp. 153158. ISBN 9781942401575 Available at https://centaur.reading.ac.uk/78023/

It is advisable to refer to the publisher's version if you intend to cite from the work. See Guidance on citing.

Publisher: ARC

All outputs in CentAUR are protected by Intellectual Property Rights law, including copyright law. Copyright and IPR is retained by the creators or other copyright holders. Terms and conditions for use of this material are defined in the End User Agreement.

\section{www.reading.ac.uk/centaur}

\section{CentAUR}

Central Archive at the University of Reading 
Reading's research outputs online 
THE FUTURE OF LITERARY ARCHIVES 


\section{COLLECTION DEVELOPMENT, CULTURAL HERITAGE, AND DIGITAL HUMANITIES}

This series publishes both monographs and edited thematic collections in the broad areas of cultural heritage, digital humanities, collecting and collections, public history, and allied areas of applied humanities. In the spirit of our mission to take a stand for the humanities, this series illustrates humanities research keeping pace with technological innovation, globalization, and democratization. We value a variety of established, new, and diverse voices and topics in humanities research, and this series provides a platform for publishing the results of cutting-edge projects within these fields.

The aim is to illustrate the impact of humanities research and in particular reflect the exciting new networks developing between researchers and the cultural sector, including archives, libraries and museums, media and the arts, cultural memory and heritage institutions, festivals and tourism, and public history.

\section{Acquisitions Editor}

Danièle Cybulskie

\section{Evaluation and Peer Review}

The press has every proposal independently evaluated by expert reviews before any formal commitment is made by the press to the author. Further, all submitted manuscripts are subject to peer review by an expert chosen by the press. 


\title{
THE FUTURE OF LITERARY ARCHIVES: DIASPORIC AND DISPERSED COLLECTIONS AT RISK
}

\author{
Edited by
}

DAVID C. SUTTON with ANN LIVINGSTONE 


\section{British Library Cataloguing in Publication Data}

A catalogue record for this book is available from the British Library

\section{(C) 2018, Arc Humanities Press, Leeds}

cc) (i) $\fallingdotseq$ (5) This work is licensed under a Creative Commons Attribution-

NonCommercial- NoDerivatives 4.0 International Licence.

The author asserts their moral right to be identified as the author of their part of this work.

Permission to use brief excerpts from this work in scholarly and educational works is hereby granted provided that the source is acknowledged. Any use of material in this work that is an exception or limitation covered by Article 5 of the European Union's Copyright Directive (2001/29/EC) or would be determined to be "fair use" under Section 107 of the U.S. Copyright Act September 2010 Page 2 or that satisfies the conditions specified in Section 108 of the U.S. Copyright Act (17 USC §108, as revised by P.L. 94-553) does not require the Publisher's permission.

ISBN: 9781942401575

e-ISBN: 9781942401582

\section{https://arc-humanities.org}

Printed and bound by CPI Group (UK) Ltd, Croydon, CR0 4YY 


\section{Appendix I}

\section{AUTHORS AND THEIR PAPERS: A GUIDANCE SHEET FOR AUTHORS AND WRITERS}

1. Rationale. Authors' literary papers are precious to cultural heritage and to scholarship, and many have wider popular appeal. They inform literary and biographical studies, textual studies, cognitive studies, and many areas of research. Above all, they are precious because of the information they provide about the creative process and what influences this, recording successive versions, drafts and variations. The preservation of these papers in public institutions will be welcomed by a wide range of users, in various fields of education, lifelong learning, biographical and cultural research and the creative arts, and the wider public. Authors are encouraged to think in terms of each literary work as passing through several archival stages of development and to seek to preserve each stage. When this guidance refers to "papers" this means all of the materials relating to an author's working life, in whatever format-paper or digital, or audiovisual.

2. What to keep. Authors may often be tempted to destroy early plans and discarded drafts. These should be kept wherever possible. Libraries and archives are interested in collecting early drafts, notebooks, handwritten and typescript versions, working notes, study notes, and research material in any format. In addition, there is an interest which extends beyond literary research:

- in correspondence: both incoming mail and drafts and copies of outgoing mail; both personal and professional correspondence;

- in emails, audio-visual materials (literary and personal), diaries, journals, and commonplace books;

- in disks, memory-sticks, and computer drives;

- authors' personal libraries are also of great interest, especially where books and journals are annotated.

All kinds of materials and correspondence relating to literary festivals, reading tours, conferences, seminars and literary organizations should be regarded as an integral part of any author's archive. In determining what to keep, authors 
should bear in mind that, in addition to illustrating the creative literary process, their papers are likely to have a wider cultural and historical interest. If the literary work has been influenced by visual arts, music, or other forms of expressive culture then the author's information on these, programmes of concerts, exhibitions, and events would also constitute a vital part of a full "author's archive." In short, all the raw material relating to a writer's life and work is likely to be of interest to an archive service and to researchers.

3. Digital records, web content and downloads. Archivists are increasingly aware that much of an author's archive is likely to be created and stored in digital form. Whilst acknowledging that digital formats may lead to increased privacy concerns for authors, archivists are keen to build collections which include digital records as well as email correspondence and online content. Personal web browsing histories are also important, as are collections of downloads, which may be the equivalent of a twenty-first-century version of the "author's library." Similarly, authors' professional correspondence is likely to include transactions with companies such as Amazon, Google Books and, providers of online services and cloud-storage.

4. How to keep it. Authors should try to keep these archival materials dry and clean and safe -avoiding lofts, garages, and garden sheds, because these are at risk from damp, changes in temperature, dirt, and pest damage. The storage area should be clean, dry and secure. Materials should be stored in acid free boxes and folders. Printed photographs should be stored in archival polyester sleeves. Metal filing cabinets are excellent, if space permits. Disks and electronic copies should be stored in their original packaging, or other containers designed for that purpose. They should not be stored in drives for long periods of time.

5. Transferring papers to an archives service: choosing the most appropriate archives. The choice of repository is a key part of the process, whether the author is donating or depositing. The recommended practice is to consult a nearby archivist or to check an appropriate Location Register (e.g. www. locationregister.com or National Register of Archives), to find out which institutions already have collections of similar materials. The Literary digest on the Accessions to Repositories survey provides information on collections taken in by archives each year: www.nationalarchives.gov.uk/accessions/

Authors can consult with interested organisations such as GLAM (the Group for Literary Archives and Manuscripts), the Society of Authors, or Archive Sector Development at the National Archives. Authors should take time to ensure that they make the right choice of archive service for donation or deposit, and this may require a period of negotiation and discussion. It is important that there is sympathy and synergy between the author's collection and the archival institution which will be responsible for its care and promotion. Seeking to change archive service once the process is underway can be a difficult process. 
6. Transferring papers to an archives service: gift, bequest, permanent loan, or deposit. There should be a deed of gift, bequest, or deposit, covering all the following points. Gift is a better long-term solution than temporary deposit. If a loan or deposit is made the repository may expect a contract including reimbursement for sorting, cataloguing, and storage, and right of first refusal in the event of withdrawal and/or sale. Although financial considerations may be paramount, often they are not.

Gift (or where appropriate, sale below probable market value) may allow the author a greater measure of control over the conditions of use, cataloguing, and storage of the collection

7. Sale of papers and archives. Some authors choose to place their archive for sale by auction, but in that case the archive may end up in one or several repositories anywhere in the world. Archives are most valuable when kept together as a complete collection and are easier to access and use for research. It is strongly recommended to keep a collection together, even if the decision has been made to sell. When a collection is broken up or "dispersed" it is difficult to find all of the component parts. In the event of an open-market sale, the archive service or purchaser will usually take control of all rights except copyright.

The National Archives monitor the sale and movement of archives collections across the UK. Advice on the sale of archives, including related legislation and tax is available online and on request. www.nationalarchives.gov.uk/archivessector/cultural-property.htm

8. Valuation. In cases where open-market sale is considered, a proper independent valuation should be obtained before proceeding with the sale. In certain other circumstances, a full valuation can also be helpful (e.g. for tax purposes). The National Archives Sales Monitoring team collects information on prices realized and can provide general advice on pricing for private sales, to funders and archives seeking to purchase.

9. Offsetting value. In many countries, the value of a donated literary archive can be offset against taxation liabilities or against death duties. This would also be dependent on an independent professional valuation. Further details are available online here: www.nationalarchives.gov.uk/archives-sector/ cultural-property.htm

10. The author's own listing of the papers. It is good practice for the author to make their own list of the materials which they have preserved, in numbered boxes and/or folders. Correspondence may be listed chronologically, year by year, or alphabetically, correspondent by correspondent. Generally, both researchers and valuers find $\mathrm{A}-\mathrm{Z}$ arrangement by correspondent more useful. It is helpful if, with correspondents who sign only with forenames or nicknames, the author adds the surname in pencil, to the folder or to a slip of clean paper inserted in the document. 
11. Terms of transfer: storage. With a gift, conditions of storage should be specified. Many archive services are able to provide optimal storage conditions, though smaller services may not be able to achieve this. The recognised standard is PD5454, which applies to all formats of archival material and specifies the ideal temperature and humidity controls for archival storage. The collection should be stored in acid-free archival boxes or folders, on shelves and never on the floor. Authors should seek assurances that their own collection will be stored at least as well as the main collections already owned by the institution - storage areas should be clean, dry, secure, protected from light, and environmental conditions should be stable. Guidance is available from the British Library: www.bl.uk/aboutus/stratpolprog/collectioncare/ publications/booklets/basic_preservation.pdf

12. Terms of transfer: cataloguing. With a gift, there should be an agreed commitment to catalogue the collection within a definite time-period, prior to making it fully available to the public. Two years for a small collection and three years for a larger collection might be considered reasonable. There may be opportunities to seek external funding to support the process of sorting and cataloguing and this can be discussed as part of transfer negotiations.

13. Terms of transfer: access and use. Once catalogued, the collection should have clear terms of access and use. For example, these could range from:

- "free access to all parts of the collection;"

- through "mostly free access; some highly personal papers closed until 2035;"

- to "access only by permission of the author during the author's lifetime."

Researchers and archivists will prefer the lightest restrictions, or none, but the author can specify. Authors should be aware that some archives institutions will find it difficult to take in collections with too many restrictions on access.

14. Terms of transfer: copyright. It should be specified whether copyright is retained by the author or transferred to the repository. Copyright should not affect access, but should control the ability to quote or make copies. The author may prefer to retain copyright but to agree a "management arrangement" with the repository (e.g. major enquiries only to be referred to the author). Some parts of an author's archive may contain the copyright of others, usually described as "third party" copyright. Archivists can advise on this further as part of transfer discussions. Further information is available online from the Information Commissioners Office: www.gov.uk/government/organisations/ intellectual-property-office

15. Terms of transfer: rights to make copies. The author should consider the extent to which they are content for copies to be made of their paper and digital literary archives. In the case of an open-market sale, the author would be unlikely to have control over this. With a gift or a private sale agreement, authors can specify their terms. They could specify a maximum of 30 pages 
for any one researcher, for example; or could insist upon no copying at all for the first five years following transfer. This may depend upon the personal sensitivity of the papers' contents; if there is no such sensitivity then a more generous approach to copying could be taken.

16. Terms of transfer: weeding. The deed of gift or deposit should specify the arrangements for weeding a collection. Weeding is the removal or "weeding out" of unwanted or irrelevant material, and duplicate copies. The author may wish to weed certain documents before transfer; the repository would normally prefer that this was not done in advance. It is better for the archivist to weed collections, as they can ensure that valuable information is not removed, and apply professional and ethical expertise. With gifts or deposits of nonliterary collections, repositories are often given "weeding rights." With a literary collection, the author might specify weeding of "printed duplicates only; no manuscript material."

17. Terms of transfer: repository's rights of use. The repository will expect the right to use selected material for exhibitions, displays, catalogues and not-forprofit publications. The author should be fully credited in all such ventures. Living authors should be offered the opportunity to participate fully in events and promotions, and, if collections contain highly personal materials, may wish to have a right of veto or closure over the selection of materials for display or publication. As collections of literary papers are often newsworthy, arrangements for publicity should be fully discussed and agreed at the time of gift, bequest, or deposit.

18. Terms of transfer: digitization. The deed of gift or deposit should have a clause on digitization. With literary archives a normal clause might be that digitization would be "only by permission of the author during the author's lifetime." It is important to recognize, that researchers' expectations are growing and that pressure for early digitization of archival collections will continue to increase. Digitization can include commercial licensing to generate income and the author and receiving archive can discuss the potential and the terms of such an arrangement.

19. Other considerations: conserving born-digital materials. Many archivists now collect born-digital material, including emails, websites and documents. They are best placed to give advice about conservation of born-digital literary materials. Advice should be sought at an early stage in cases where an author typically works straight onto a computer. Authors who produce mainly digital drafts and documents should take steps to preserve access to these materials over time. Digital records require active preservation to ensure that they are accessible even in the short- to medium term. Basic advice and further sources are available online here: www.nationalarchives.gov.uk/documents/ archives/digital-preservation-guidance-how-to-look-after-arts-records.pdf

20. Other considerations: publishers and literary agents. Authors who are entering into an arrangement with a collecting institution will wish to check 
with their publisher(s) and literary agent(s) as to which of their papers are held by those organizations. It may happen that such papers should belong to the authors but have been retained by their representatives, or there may be a mixture of material. Again, publishers and agents should be involved in discussions where possible, especially where there are commercial or copyright considerations.

Compiled by representatives of;

Diasporic Literary Archives Network (DLAN)

Group for Literary Archives and Manuscripts (GLAM)

Society of Authors (SoA)

The National Archives (TNA)

Other sources of guidance:

Hull History Centre, Personal Papers: www.hullhistorycentre.org.uk/discover/ hull_history_centre/about_us/caring_for_the_collections/personalpaper.aspx

Staffordshire Archives Safekeeping: www.staffordshire.gov.uk/Resources/Docu ments/i/InformationLeaflet03Insafekeeping.pdf

Religious Archives Group, Advice on Personal Papers: http://religiousarchives group.org.uk/advice/rag

The National Archives, Advice on Deposit: www.nationalarchives.gov.uk/docu ments/archives/loanagreement.pdf

The National Archives, Archival Principles and Practice: http://webarchive. nationalarchives.gov.uk/+/http://www.nationalarchives.gov.uk/documents/ information-management/archive-principles-and-practice-an-introductionto-archives-for-non-archivists.pdf

The National Archives, Archiving the Arts resources: www.nationalarchives.gov. uk/archives-sector/archiving-the-arts-resources.htm 